\title{
CHOLERA, NUISANCES AND ENVIRONMENTAL MANAGEMENT IN ISLINGTON, 1830-55
}

\author{
Gerry Kearns
}

The concentration of an increasing population in towns altered the relations between society and nature. In ecological terms, environmental management may thus be seen as an adaptive strategy. During the nineteenth century the responsibilities of property owners were adjusted to comprehend a more extensive set of obligations towards the public health. Local governments were charged with policing these new obligations. Public health reform was an important issue in municipal politics, involving interference with property, and expenditure on environmental improvements. The degree and effectiveness of local sanitary activity varied from place to place, in line with the local balance between pressures for and obstacles to these interventions. Among the forces impelling public health efforts was the perceived environmental degradation of the growing cities. Historians and contemporaries have drawn attention to the fear engendered by epidemic disease such as cholera. Flinn wrote that:

Cholera was swift, dramatic, highly lethal while it lasted and extremely contagious. It struck terror into the minds of the middle and upper classes who ruled the cities and the country, and accordingly led, as no other disease did in the first half of the nineteenth century, to immediate, vigorous, administrative action. ... [C]holera had galvanised otherwise moribund corporations into temporary frantic activity. ${ }^{1}$

A contemporary public health pamphleteer, William Guy, reminded the public of the encouragement the first cholera epidemic (1831-2) had given to local sanitary efforts: "When the cholera did us the favour to pay us a visit (I speak seriously, it was a favour), we made preparation for its reception. We cleansed out many an Augean stable, set the scavengers to work in right earnest, whitewashed sundry houses, and showed a wholesome respect for the threatened invader."2

The effectiveness of the temporary local boards of health set up during the cholera epidemic of 1831-2 has been questioned. Durey has concluded that "overall the local boards failed" and that "what was needed was a strong and purposeful lead from

Gerry Kearns, Ph.D., Department of Geography, University of Liverpool, Roxby Building, PO Box 147, Liverpool L69 3BX.

${ }^{1}$ Edwin Chadwick, Report on the sanitary condition of the labouring population of Great Britain (1842), ed. M. W. Flinn, Edinburgh University Press, 1965, 10.

${ }^{2}$ W. A. Guy, Unhealthiness of touns, its causes and remedies, London, Charles Knight, 1845, 25. 


\section{Environmental management in Islington 1830-55}

central government". 3 By the time of the second cholera epidemic (1848-9), the organization of local government had been changed by the reform of some municipal authorities and, more importantly, by the reorganization of the English Poor Law into a national system characterized by a strong and purposeful central Poor Law Board. Edwin Chadwick, who provided a strong and purposeful lead from the Poor Law Board (1834-47) and General Board of Health (1848-54), as well as through parliamentary inquiries and extensive correspondence, was clear both about the inactivity of unreformed local authorities in 1831-2 and about the need to proceed through the centrally-accountable Poor Law Boards of Guardians in promoting the public health:

The Diseases Prevention Act contemplated the Poor Law Boards generally as the most eligible local administrative bodies for the execution of its provisions. With the aid of the staff of medical officers, and with the fever wards of the Union [work]houses as provided in England and Wales, there can be no doubt that they are far more eligible bodies than the common parochial bodies, which were the only ones in 1832.4

Overlying the promptings of sickness and smells, then, were the responsibilities placed on local authorities by legislation such as the Nuisances Removal and Diseases Prevention Acts and the Public Health Acts, ${ }^{5}$ as well as those transmitted to Poor Law Boards of Guardians by the Poor Law Board and the General Board of Health (set up in 1848).

The problems faced by local authorities in responding to these pressures for improvement included the multiplicity of bodies responsible for the urban environment. In London many of them were swept away by the Metropolis Management Act of 1855, but, as Chadwick replied to a concerned clergyman from St Pancras during the 1848-9 epidemic,

In the parish of St. Pancras where you reside there are no less than sixteen separate Paving Boards, acting under twenty-nine Acts of Parliament which would require to be consulted before an opinion could be safely pronounced as to what it might be practicable to do for the effectual cleansing of the parish as a whole. ${ }^{6}$

Chadwick himself considered that the major impediment to activity was ignorance:

\footnotetext{
${ }^{3}$ M. Durey, The return of the plague: British society and the cholera 1831-2, Dublin, Gill \& Macmillan, 1979, 95.

${ }^{4}$ British Parliamentary Papers (PP) 1850 (1273) xxi, p. 3, 'Report from the General Board of Health on the Epidemic Cholera of 1848 and 1849' ('General Board of Health on Cholera'), 137.

59 \& 10 Vict., c. 96, An Act for the more speedy removal of certain Nuisances, and to enable the Privy Council to make regulations for the Prevention of contagious and epidemic Diseases until the twenty-first day of August one thousand eight hundred and forty-seven, and to the end of the next Session of Parliament (28 August 1846). 11 \& 12 Vict., c. 63, An Act for promoting the Public Health (31 August 1848). 11 \& 12 Vict., c. 123, An Act to renew and amend an Act of the Tenth year of Her present Majesty, for the more speedy removal of certain Nuisances, and the Prevention of contagious and epidemic Diseases (4 September 1848).

6 Public Record Office (PRO) MH13, 'General Board of Health and Local Government Act Office, Correspondence', vol. 261, 15 November 1848.
} 
The chief obstacles to the general and early adoption of measures of prevention arise from the difficulty of communicating to those whom it is necesary to convince, such information as may satisfy their minds of the incomparable [sic] greater efficacy of measures of prevention than of those that are merely palliative or curative. ${ }^{7}$.

The social costs of disease meant, according to Chadwick, that prevention was not only more effective but also cheaper than cure, so that the defence of the rates by Chadwick's "meanest class" of shopkeepers and landlords was a short-sighted policy doomed to dissolve in the face of the scientifically-grounded "sanitary idea". As far as the vested interests were concerned, though, this equation between short-term costs borne by property and long-term benefits accruing to society did not balance. The defence of local autonomy incorporated a refusal on their part to recognize the new responsibilities placed upon property. ${ }^{8}$ The New Poor Law from 1834 provided a focus for this opposition to central interference, and the decision to give public health duties to the Poor Law Boards of Guardians, therefore, brought its own problems. Until 1867, many of London's local authorities were not constituted as Poor Law Unions under the New Poor Law and persisted with local Acts which gave them a degree of autonomy from central interference. St Mary, Islington, was one such parish.

Islington was a large, North London parish (see figure 1) that was rapidly built up over the period $1830-55,{ }^{9}$ when its population rose from under 40,000 to more than 110,000 . During this period the population of England and Wales rose from 14.0 million to 18.5 million and London's from 1.6 million to 2.5 million. Islington's annual rate of growth of 4 per cent was above the national average of 1 per cent and London's average of 2 per cent. By decade, it fluctuated as follows: $5 \cdot 2$ per cent in $1821-31,4.0$ per cent in $1831-41,5 \cdot 5$ per cent in $1841-51$, and 5.0 per cent in $1851-61$. London's rate mirrored these changes exactly: $1.8,1.6,1.9$, and 1.7 per cent respectively. Taking the twenty-two largest English provincial cities in 1851, seventeen of them grew faster than London in 1821-31, fourteen in 1831-41, eleven in 1841-51, and ten in 1851-61. None exceeded Islington's rate of growth in any of the decades, and its population in 1851 would have placed it in the middle of this list of cities. Of course, to compare part of one city with all of several others may be misleading, but it does help to make the point that Islington had a large and rapidly increasing population. ${ }^{10}$

For much of this period, great stretches of Islington were effectively building-sites. In pockets, however, it had rates of overcrowding characteristic of the East End. By the middle of the century, the noxious trades of London had largely been driven out of the city centre, as far as places like Islington. In many ways, the movement of the

\footnotetext{
7 'General Board of Health on Cholera', 148.

${ }^{8}$ See M. Brayshay and V. Pointon, 'Local politics and public health in mid-nineteenth-century Plymouth', Med. Hist., 1983, 27: 162-78.

9 This map is based on the $12^{\prime}$ Ordanance Survey skeleton maps showing roads and streets surveyed 1848-50 and described in I. Darlington and J. Howgego, Printed maps of London circa 1553-1850, London, George Phillip \& Son, 1964, no. 412, 38-40.

${ }_{10}$ These data are discussed more fully in G. Kearns, 'Aspects of cholera, society and space in nineteenth-century England and Wales', Cambridge University PhD thesis, 1985, chs 2 and 4.
} 
Environmental management in Islington 1830-55

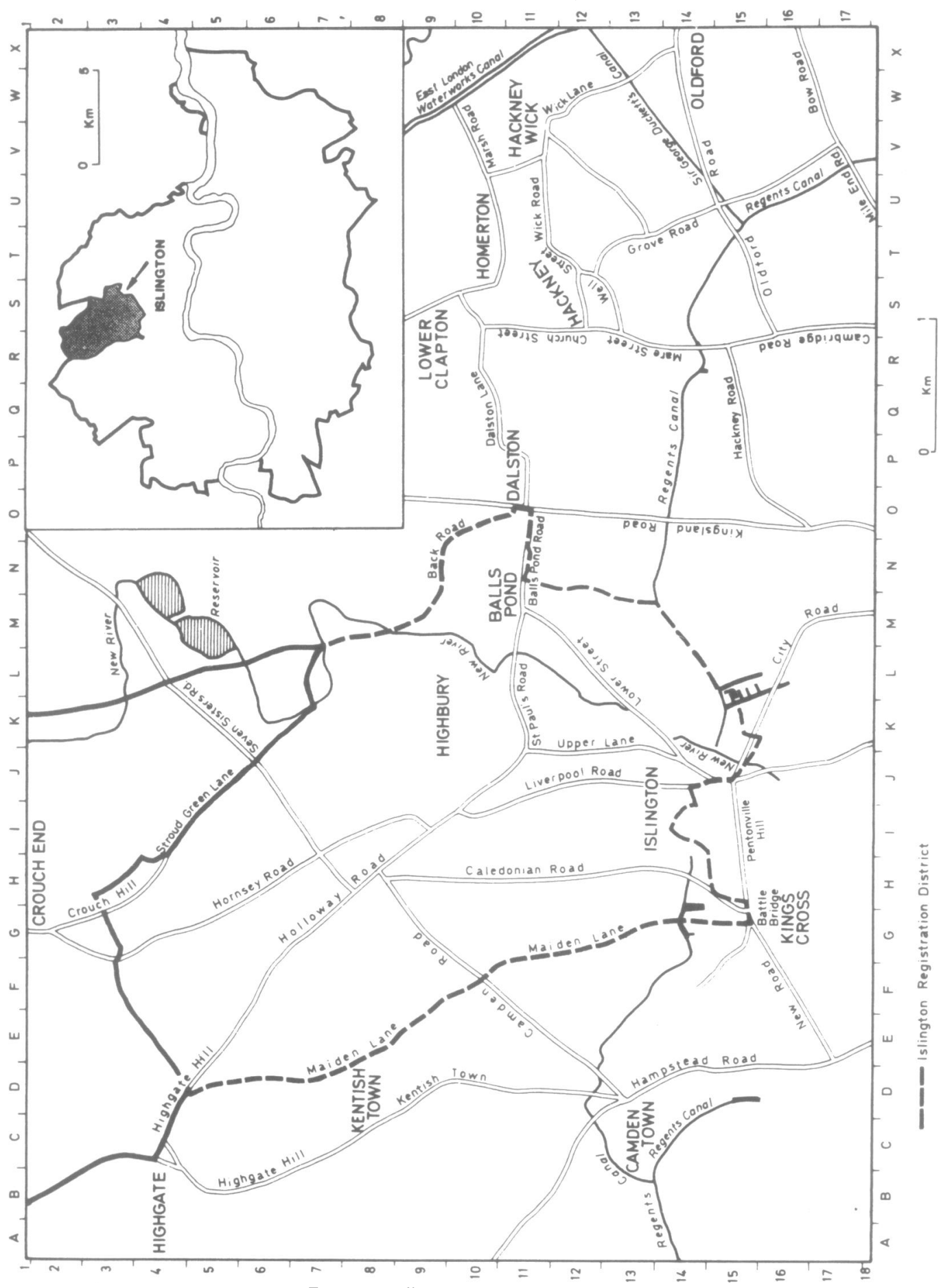

Figure 1 Islington and its environs. 
City of London's live cattle market from Smithfield to Copenhagen Fields, Islington, in 1855 was a response to a set of pressures before which less powerful property owners than the Corporation of the City of London had already submitted. Islington, therefore, had rather special public health problems and with its cowkeepers, pigkeepers, refuse processors, small builders, and chemical works it exemplified many of the environmental hazards to which the public health movement drew attention. Yet, its poor, its bad drainage, and its overcrowding were sufficiently diluted by its middle and lower-middle classes, its elevation, and its open spaces for it to be one of London's healthier registration districts. Whereas London was repeatedly ravaged by cholera, Islington was more favoured. In the cholera epidemics of 1831-2 and 1848-9, about one-quarter of the victims in England and Wales died in London, giving it a rate of cholera mortality (3.8 and 5.2 per thousand respectively) double the national rate. In 1853-4, the disease was even more heavily concentrated in London and there the rate of 4.3 cholera deaths per thousand included nearly half the national total of 21,960 cholera fatalities. Islington's cholera mortality rates of $1 \cdot 0,2 \cdot 2$, and $0 \cdot 9$ per thousand, respectively, were below the national average on each occasion. For 1849 and 1854 , it is also possible to compare these cholera mortality rates with rates of mortality from all causes. In England and Wales these were 25.2 per thousand in 1849 and 23.9 in 1854 , for London the comparable figures were 30.2 and 30.8 , and for Islington $22 \cdot 1$ and $25 \cdot 9$. Clearly Islington was a relatively healthy part of London, but the 1854 mortality rate indicates some deterioration: it was, for example, worse than that in four provincial cities (Bolton, Brighton, Bristol/Clifton, and Leicester) among the twenty-two mentioned above.

Islington's particular environmental problems, ${ }^{11}$ its rapid growth, and its fiercelyguarded independence make it an interesting place to study. It stood out against the New Poor Law of 1834 until 1867, and acted with many other North and West London parishes to frustrate the intentions of the Poor Law Board with regard to education, workhouse management, and the establishment of Metropolitan Asylum Districts. Moreover, Islington is documented by an embarrassing wealth of local records. The division of reponsibility between the different committees of the Board of Trustees of the Parish was frequently an administrative convenience and changed in line with the ebb and flow of interest and business. Consequently, in studying the local history of public health efforts a relatively complete set of archives may often be vital. After 1855 and the Metropolis Management Act, there was an explosion of good local journalism in the various parts of London; so much so that Owen has written that, in his studies of London local government during the tenure of the Metropolitan Board of Works (1855-89), he invariably found the local press more informative than local government minute books. ${ }^{12}$ Before 1855, Islington was not favoured with such good newspaper coverage and one must fall back on local archives. Fortunately, they are both extensive and detailed. In this brief survey they are used to examine the chronology of public health activity in Islington with

\footnotetext{
11 These are described in B. Connell, 'An examination of the incidence of mortality in Islington, 1856', Department of Geography, Polytechnic of North London BA disseration, May 1985.

${ }_{2}$ D. Owen, The government of Victorian London 1855-89: the Metropolitan Board of Works, the vestries and the City Corporation, London, Havard University Press, 1982.
} 
reference to four central concerns: the range of public health responsibilities discharged by the local government, the forces promoting and containing its efforts, the distinctiveness of the authority's response to perceived epidemic threats, and the nature of the authority's relations with central government.

\section{THE LEGAL FRAMEWORK OF SANITARY MEASURES}

The legal framework of sanitary measures consisted of the rights and reponsibilities of private property, private companies, and local authorities. In 1830, Islington was served by at least two commissions of sewers, one water company, and one private road-cleaning company. It had at least two road-holding companies, one turnpike trust, and four landowning charities. The parochial affairs of Islington were controlled by an Open Vestry, an elected Board of Trustees of the Poor with its associated committees, and 5,000 ratepayers.

Figure 2 shows the constitution of the Parish of Islington under the Local Act of $1824 .^{13}$ The Vestry was open to all heads of households but the system of proportional voting ensured that the distribution of power within the Vestry largely reflected the distribution of property within the Parish. Ratepayers assessed at $£ 30$ or more were eligible to stand for election to the Board of Trustees. The Board of Trustees appointed the various executive committees of the Parish while the Vestry was responsible for interpreting the Local Act for the Board, and through its auditors and assessors could, and did, hold Trustees personally responsible for "illegal"

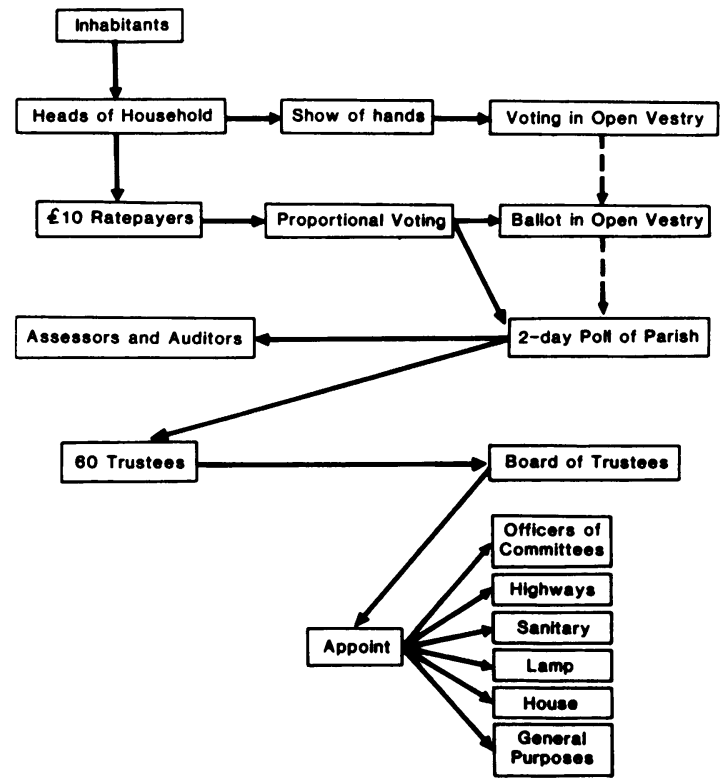

Figure 2 The Constitution of the Parish of St. Mary Islington under the local act of 1824.

13 5. Geo IV, c. 125. An Act to repeal several Acts for the Relief and Employment of the Poor of the Parish of St. Mary Islington in the county of Middlesex; for lighting and watching and preventing Nuisances therein; for amending the Road from Highgate through Maiden Lane, and several other roads in the said Parish; and for providing a Chapel of Ease and an additional Burial Ground for the same; and to make more effectual provisions in lieu thereof (17 June 1824). 
expenditure. Where a difference of opinion existed over the interpretation of the Local Act, parties had the right to seek the opinion of counsel and ultimately to pursue the matter to the Court of the King's Bench. The Local Act gave the Board of Trustees the right and responsibility of proceeding against parties who prejudiced the public's right to enjoy full use of the public domain of the parish. These powers were devolved to the "Committee of Highways and Footpaths, Sewers and Drains" and the "Committee of the Lamp and Watch", both appointed by the Trustees.

The distinction between public and private domains within the parish is the single most important legal fact which affected sanitary activity on the part of the parish authorities. In two areas, the distinction was of particular significance. First, with respect to sewers and drains, the Trustees assumed responsibility only for "ancient" (or natural) watercourses and for those channels which were not under distinct private ownership. That is, they were not responsible for drains cut by individuals on their own land. Nor did the Board of Trustees have control over channels owned by the Holborn and Finsbury Commission of Sewers or the Tower Hamlets Commission of Sewers.

The second area in which responsibility was shared was with respect to roads and pavements of which many were held by private individuals, road-owning companies, and turnpike trusts. Under the Local Act of 1824, as clarified by the Trustees on 15 October 1828, the Board of Trustees admitted a continuing obligation to clean and maintain its own roads. ${ }^{14}$ In this rapidly growing parish the construction and maintenance of good new roads were important. By establishing certain minimum standards, which had to be met by any roads that the parish might adopt, the Trustees tried to impose higher standards on builders and developers. The Trustees would take on new roads and have them cleaned and repaired only if the original owners invited them to do so and the roads had been built according to the recommendations of the Highway Committee's Surveyor ${ }^{15}$ with a minimum width of 30 feet. $^{16}$ In these cases the Board of Trustees contributed about one-third of the cost of making the road. ${ }^{17}$ They also reserved the right to take on roads built before 1825 even where they did not meet these regulations for new roads. ${ }^{18}$ The "cleaning" of roads appears to have covered sweeping and occasionally watering. Repairs would have entailed making good any potholes, ensuring effective drainage, and restoring the camber.

Once every three months from May 1840, the minutes of the Highway Committee record the names of the roads cleaned and repaired. Although it is not possible to determine from this source the initial responsibilities of the Board of Trustees, their growing obligations may be roughly charted, for, once a road had been cleaned, its upkeep fell to the parish authorities. Figure $3^{19}$ indicates the maintenance of the Trustees' roads. On average, between 60 and 70 per cent of their roads were cleaned in

\footnotetext{
${ }^{14}$ Islington Public Library (IPL), YL/385 98313-22, 'St Mary Islington. Committee of Highways and Footpaths, Sewers and Drains. Minutes 1830-56' ('Highways'), 29 December 1831.

15 Ibid., 6 April 1841; 15 April 1841.

16 Ibid., 9 March 1841.

${ }^{17}$ Ibid., 17 October 1833.

${ }^{18}$ IPL, YL 385/98387-407, 'St. Mary Islington. Trustees of the Parish of St. Mary Islington. Minutes 1824-66' ('Trustees'), 2 March 1836.

${ }^{19}$ Based on IPL, 'Highways', May 1840 to December 1847.
} 


\section{Environmental management in Islington 1830-55}

any one year. The most important thoroughfares were repaired more regularly, but as figure $4^{20}$ shows, over half of all the Trustees' roads were repaired at least once a year and over 80 per cent were repaired at least once every three years. In June 1841, their Surveyor reported to the Highway Committee that there were 288 roads in the parish and a total road length of 21 miles. ${ }^{21}$ By the end of 1847 , the total length of roads in the parish was 25 miles, the Board of Trustees' responsibilities had increased from 169 to 466 roads. ${ }^{22}$ About half this increase may be accounted for by the incorporation of the bulk of the remainder of the Surveyor's 1841 list into the Board's holdings, and the four miles of new roads probably accounts for the rest. Despite this extension of their activities, the Board of Trustees' General Sanitary Committee, appointed in November 1848 to implement the Cholera Regulations of the central government's General Board of Health, told the Trustees that "unmade roads" were "the great obstacle to the completion of the sanitary improvement of the parish". ${ }^{23}$ This General Sanitary Committe initially set up five district committees to survey and monitor the health of the parish. One of these District Committees found forty-one roads "which owing to the negligence of the owners are in an unfinished state and not under the

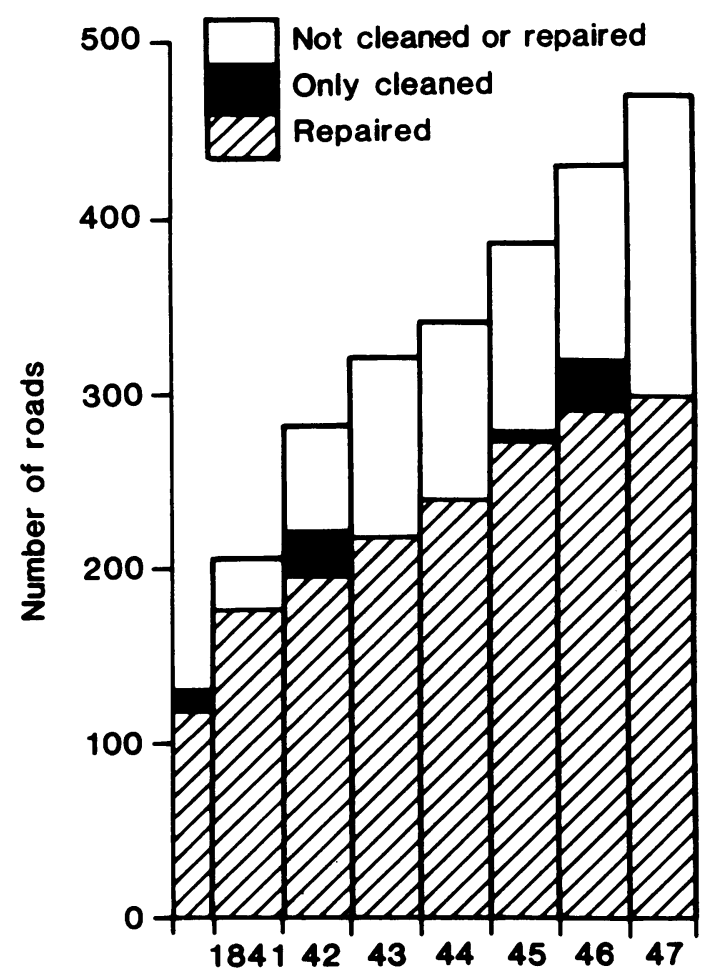

Figure 3 The maintenance of the roads of the parish of the Board of Trustees, May 1840 to December 1847.

20 Ibid.

21 Ibid., 1 June 1841.

22 Ibid., 16 December 1847.

${ }^{23}$ IPL, 'Trustees', 17 January 1849. 


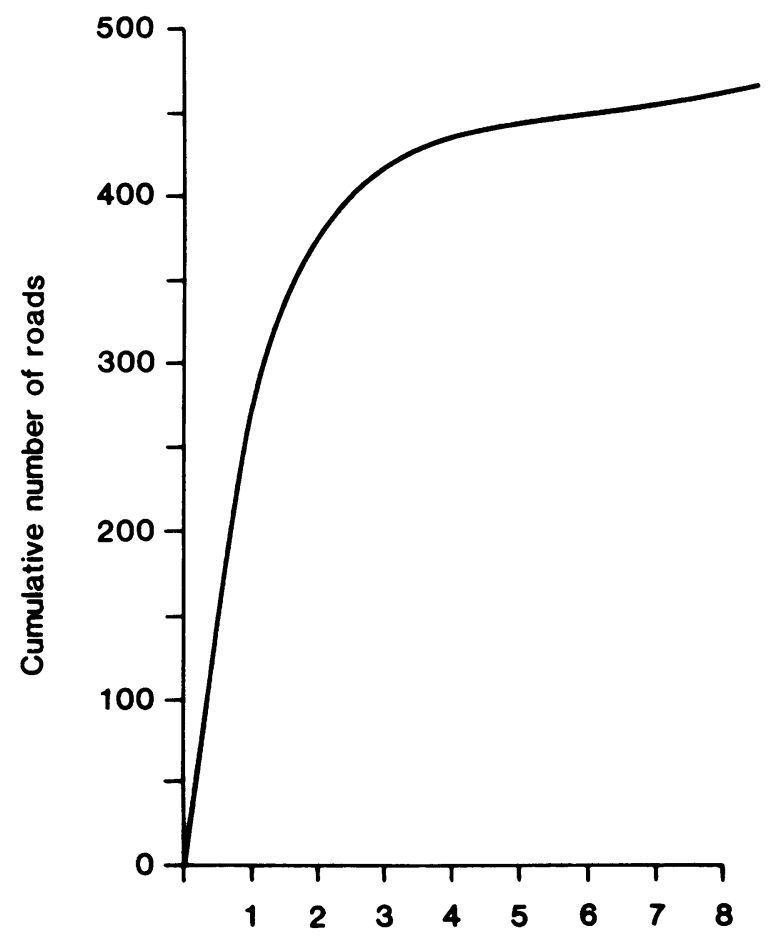

Average interval between repairs (years)

Figure 4 The average interval between repairs for the Trustees' roads, May 1840 to December 1847.

jurisdiction of the Trustees" and "all of which ought to be made as speedily as possible". ${ }^{24}$

The division of the parish into public and private domains was a changing one but it was a central feature with which all efforts at improving the environment had to deal. This distinction was vital in setting the terms of reference of the local authority's responsibilities. Sanitary problems were treated within the law as "nuisances". Four sets of legal sanctions were used at various periods to secure the removal of nuisances: common law; Islington's Local Act of 1824; the Nuisances Removal and Diseases Prevention Acts of 1846, 1848, and 1853; and, finally, the regulations of the central government's General Board of Health from 1848. No doubt, many troubles were cleared up out of a spirit of good neighbourliness, but behind much public health activity lay the threat, albeit often an empty one, of legal sanctions against the unco-operative. A successful prosecution along these lines might result in the defendant paying all costs, the costs of necessary improvements or simply a fine. Such cases came before a Police Magistrate and not a jury.

Common law, as Chadwick noted,

${ }^{24}$ Ibid., 3 January 1849. 


\section{Environmental management in Islington 1830-55}

Declares the Englishman's birthright to be ... a right..."to three great commodities, that is to say air for his health; light for his profit; prospect for his pleasure"... A Common Nuisance is defined to be an offense against the public "either by doing a thing which tends to the annoyance of all the King's subjects or by neglecting a thing which the common good requires". ${ }^{25}$

The apparent simplicity of a procedure that protected an individual's right to the enjoyment of his property was undermined by the chaotic state of case law on this topic and because "the remedy by indictment is so uncertain and so expensive as to place it beyond the reach of private individuals". ${ }^{26}$ The Local Act of 1825 placed upon the Board of Trustees the obligation to secure the same rights for individuals with respect to public realm of the parish. The Nuisances Removal and Diseases Prevention Act made the Common Law easier to use in cases where the nuisance was prejudicial to health. It recognized the local authority as a competent body to proceed against offenders, although indictment required the signed complaints of two inhabitants, the certificate of a qualified medical practitioner that the nuisance was "injurious to health", and a hearing before a magistrate. These proceedings were undertaken by the Board of Trustees from 1846 to November 1848, when they were devolved to their General Sanitary Committee. The Regulations of the General Board of Health empowered local authorities to appoint local Boards of Health, which were to carry out the sanitary recommendations of the General Board. In addition to using the powers of the Nuisances Removal and Disease Prevention Acts, the local Boards were to appoint medical visitors, clean streets, channels and houses, and, under certain circumstances, institute house-to-house visitation in poorer districts to treat people with diarrhoea, since the General Board saw all these as potential cholera cases. Islington appointed a General Sanitary Committe and five District Sanitary Committees on 22 November $1848,{ }^{27}$ the district committees were reduced to two on 28 February $1849 ;^{28}$ and the General Sanitary Committee was dissolved on 28 November that year, when these two district committees were combined into one Nuisances Committee. ${ }^{29}$

The Regulations of the General Board of Health were the only legal sanctions restricted to epidemic years. In other words, nearly everything the local authority did to cope with cholera, it was legally entitled to undertake at other times also. In fact, in 1832 this was perforce the case since the Boards of Health set up in Islington had no powers beyond those of the Local Act. ${ }^{30}$ If the local authority used its powers differently during cholera epidemics, it must largely be because it was under greater pressure to do so.

\footnotetext{
${ }^{25}$ University College London, Chadwick Collection, MSS.57, 'Notes on Nuisances exemplified at Lambeth and the need of summary remedies'.

26 Ibid.

27 IPL, 'Trustees', 22 November 1848; the committee was apointed on the recommendation of the General Purposes Committee of the Trustees in view of the General Board of Health Regulations.

28 Ibid., 28 February 1849.

29 Ibid., 28 November 1849.

30 The first was a Cholera Morbus Committee appointed by the Vestry on 15 December 1831, and the second was an Islington Board of Health appointed by the Privy Council on 18 July 1832 . The final reports of the two committees are in the Vestry Minutes for 21 June 1832 and 9 April 1833; cf. IPL. YL 385/98384-5, 'St. Mary Islington. Vestry Minutes 1824-52' ('Vestry'), 21 June 1832, 9 April 1833. The Islington Public Library also holds the minutes for 1852-6 but these are not catalogued.
} 
THE PRESSURE FOR SANITARY MEASURES

There may have been many landowners who maintained the character of their property by drawing up and enforcing strict leases, and these properties were unlikely to come within the purview of the local authority. ${ }^{31}$ There were really three distinct groups who brought pressure to bear on the local authority for the execution of sanitary measures such as cleaning streets and properties or prosecuting refractory owners or occupiers. In the first place, individual citizens might complain of intolerable and dangerous smells. For example, in October 1841, Ann Swanwick made the following complaint of her neighbour who kept pigs:

On divers days and times between the first day of August last and the date of her complaint the effluvium arising from the said stye was and is so offensive and the noise arising from the pigs kept therein being killed, was such an annoyance and the said stye was, and is, in such a dirty condition that she was and is prevented from the full and free enjoyment of her said house as she ought and is entitled to do and, therefore, the said Ann Swanwick doth request the said Trustees to view the said stye, to deem the same a nuisance and to order the same to be removed according to the provisions of the said Statute [the Local Act] in that case made and provided. ${ }^{32}$

The smell was so bad that Ann Swanwick "had been obliged to keep the window and door, at the back of her house, shut". There was a further penalty for Swanwick in that "Mrs. Woollett, a lodger, left the apartments she occupied in the said house on account of such effluvium." 33 Landlords, although not often prominent in public health movements, were anxious to interfere with the rights of other people's property when their own rents were prejudiced. Another landlord, Mr Craighill, complained in August 1843 of another piggery. The Lamp Committee of the Board of Trustees viewed the spot and concluded that "The party having promised to keep the piggeries clean the meeting does not consider the nuisance of sufficient magnitude at present to call for the interference of the Board."34 However, in September Mr Craighill returned to say "that the nuisance from the piggeries ... was not abated and that his tenants threatened to leave him in consequence". ${ }^{35}$ The Lamp Committee once again viewed the place and on that occasion "considering it a nuisance, saw Mr. Taverner, the owner of the pigs, on the subject when he promised to remove them within a fortnight from this day". 36

The second group active in promoting sanitary measures were the local officials appointed to bring infringments of the Local Act to the attention of the Trustees: the Inspector of Courts and Alleys, the Inspector of Slaughterhouses, the Inspectors of Nuisances, the Highways Surveyor, the Streetkeeper, and the Medical Officers. These employees would represent the Board of Trustees at any legal proceedings. In general,

${ }^{31}$ But see the discussion of proceedings against Harriet Parkin at p.124 below.

32 IPL, 'Trustees', 26 October 1841. Swanwick lived in Sebbon Street, a crowded part of Islington off Upper Lane (K12 in figure 1).

33 Ibid.

34 IPL, YL 385/98422-8, 'St. Mary Islington. Lamp and Watch Committee Minutes 1772-1856' ('Lamp'), 18 August 1843. The nuisance was in a small road near Liverpool Road, Little Bride Street (I 11 in figure 1).

35 Ibid., 15 September 1843.

36 Ibid., 19 September 1843. 
the Board followed up all the cases referred to it, although on one occasion it felt the need to admonish its streetkeeper after a successful prosecution of a brothel-keeper. He was told that "the Board did not approve of his conduct in employing a person to commit an immoral act for the sake of establishing the bad character of the house". ${ }^{37}$ The Inspectors of Nuisances appointed to the District Sanitary Committees from 1848 devoted their attention to monitoring sanitary conditions, but other officers of the Board of Trustees shared these responsibilities. The Medical Officer to the workhouse was particularly assiduous in repeatedly calling attention to the need for cleaning the poorer districts of the parish; for example, in the summer of 1839 the Trustees decided that "the overseers be authorised to employ persons to cleanse the courts near the turnpike from filth, the Medical Officer having reported there are several cases of fever in that neighbourhood". ${ }^{38}$ In addition to the officers specifically charged with safeguarding the public health, other parish employees reported cases as they came across them. The Assessors and Auditors were required to perambulate the parish for each reassessment and in 1844 they sent a memorial to the Trustees "complaining of the filthy state of the courts ... near the Turnpike". The Trustees instructed the Highways Surveyor "to have them cleaned" and he was further "directed to report from time to time, to the Board when the several Courts and Alleys and Bye Places in the Parish require cleansing". 39

The third group pushing for public health measures were the government bodies. Sometimes this pressure was mediated through the effect the press or official reports might have on public opinion. At other times, the pressure was exerted more directly. Examples of the former include reports in The Times of some remarks made by Thomas Wakley in a coroner's report on a death within Islington ${ }^{40}$ and, on another occasion, of some comments made by a Police Magistrate about the state of some slaughterhouses in Maiden Lane. ${ }^{41}$ In both these cases, the Board resolved that the criticisms were ill-founded. On 2 September 1846, the Trustees appointed a committee "to inquire into the most effectual and economical means of obtaining a supply of water in the localities referred to in the Surveyor's Report for the use of the Inhabitants". ${ }^{42}$ One of the documents referred to this Committee was a letter from a ratepayer, W. H. Latham, containing extracts from the Local Act relating to the Trustees' powers to erect pumps, as well as extracts from the Fifth Annual Report of the Registrar General which bemoaned the lack of clean spring-water in Islington, and concluding:

Now Gentlemen do away with that supineness which has so long been attached to the Board, move in good earnest and save the parish from dishonour and prevent Commissioners being sent in from Government for Lord John Russell in his opening

\footnotetext{
${ }^{37}$ IPL, 'Trustees', 19 March 1845.

38 Ibid., 5 June 1839.

39 Ibid., 13 November 1844 . The district referred to is positioned around $\mathrm{J} 11$ in figure 1.

40 Ibid., 24 January 1844; and The Times, 22 January 1844.

${ }^{41}$ IPL, 'Highways', 12 January 1843; and The Times 10 January 1843. Maiden Lane is at the west of the parish and at this time Belle Isle was not completely built-up (G11 in figure 1).

${ }^{42}$ Greater London Record Office (GLRO), P83/MRY1/736, 'Committee for obtaining effectual and economic water supply'; f.1.
} 
speech did say he should take notice of the sanatory condition of the different towns. ${ }^{43}$

It is significant that the Trustees felt obliged to take notice of all "official" criticisms of the sanitary state of the parish.

Government bodies that brought pressure directly to bear on Trustees included the Central Board of Health (1832), the Poor Law Commission (1834-47), the Poor Law Board (from 1847), the General Board of Health (from 1848), and the Metropolitan Sanitary Commission, which was investigating the public health of London (1847-8). Islington refused to co-operate with many central government schemes but this opposition does not seem to have been extended to matters of public health. In December 1831, the Cholera Committee of the Trustees reported to the Vestry that, on the recommendation of the Privy Council, it had published a handbill, surveyed the parish for nuisances, written to the relevant landowners to remove the nuisances, negotiated with the New River Company for an increased supply of water, and employed paupers of the parish to cleanse the courts and alleys. The Vestry thanked the Trustees "for the prompt measures taken by them". ${ }^{44}$ The efforts of the Cholera Committee were continued by the Islington Board of Health, which was appointed on 18 July 1832 by the Privy Council to carry out the instructions of the Central Board of Health. The Islington Board of Health was likewise thanked by the Vestry for "its very useful services". 45

This co-operation with central public health authorities continued after the passage of the Poor Law Amendment Act in 1834. The Poor Law Commission itself was quiet, apart from encouraging a more vigilant policy of vaccination. ${ }^{46}$ The Commission explained to the Trustees what their sanitary reponsibilities were, sending "instructions ... for carrying the provisions [for vaccination] into effect in this parish" ${ }^{47}$ It also advised the Trustees of the "salutary effect of Chloride of Zinc when used as a disinfecting agent" and recommended that it be used in the workhouse and in the "dwellings of pauper patients attacked by fever". The Trustees instructed their Medical Officer to try it out and report on its "efficacy" to the Poor Law Commission. ${ }^{48}$ Similarly, with respect to the Nuisances Removal and Disease Prevention Act, the Poor Law Board sent a letter "explanatory of the ... Act and of the duties of the Board with reference to its execution" ${ }^{49}$ These cordial relations were not replicated in many other areas of Poor Law activity.

Co-operation and respect also characterized the Trustees' relations with the General Board of Health. The London employees of the General Board of Health were men of real quality, and Islington had dealings with four independent, competent, and exacting officers of the General Board: Drs Richard Grainger, Gavin

\footnotetext{
43 Ibid., f. 12.

44 IPL, 'Vestry', 15 December 1831.

45 Ibid., 9 April 1833.

${ }^{46}$ IPL, 'Trustees', 16 July 1847.

${ }^{47}$ Ibid., 16 September 1840.

48 Ibid., 9 July 1847.

${ }^{49}$ Ibid., 11 October 1848.
} 
Milroy, John Liddle, and Hector Gavin. Grainger attended a meeting of the Board of Trustees in July 1849; he conferred with the Sanitary Inspectors and the Medical Officers, and he visited the workhouse. He criticized the provision for the cholera patients there, but "observed that he was much gratified by the activity and zeal which the Trustees had displayed in the measures they had adopted for improving the sanitary state of the parish". ${ }^{50}$ His recommendations were followed to the letter. ${ }^{51}$ In August, Grainger returned and consulted the Medical Officer about the great increase in mortality from cholera and represented the need for "making a House to House visitation in affected localities", for which three extra Medical Officers would be needed "to make a strict house-to-house visitation daily to find out, attend and treat medically on the spot all cases of diarrhoea and to find out and report to their superior officers all serious cases of sickness and attacks of cholera". This was immediately agreed to. 52

Liddle was sent by the General Board in September to "superintend the carrying out of the measures preventive of cholera". He recommended "the Board to appoint four more additional Medical Visitors" and suggested that one or two 24-hour dispensaries be opened, that each Medical Officer should have an assistant, and that all drugs should be free. ${ }^{53}$ The free supply had already been established, three of the five Medical Officers were given assistants, and the four extra visitors were appointed. No new dispensaries were opened, but the poor were allowed to take their cholera prescriptions to any druggist in the parish to have them made up. In Grainger's report on the 1849 epidemic in London, Islington is cited as "another very melancholy instance of the dire effects of a neglected sanitary condition, which, occurring on the verge of the country, shows that no advantage of this kind can counter balance the baneful influence of a locally poisoned atmosphere". 54 The high mortality in two areas might have been arrested, in Liddle's view, had people at risk been removed to Houses of Refuge, and he wrote of "the disastrous results which were caused by the guardians neglecting to comply with the order of the Board of Health directing houses of refuge to be opened". 55 The General Board of Health urged that a daily committee should meet during the epidemic. ${ }^{56}$ Such a committe was appointed and almost immediately set up a House of Refuge in the neighbourhood of Rutland Place, one of the two districts to which Liddle had drawn attention. ${ }^{57}$ The committee also employed nine nurses in Brand Street, also mentioned by Liddle. The property in these two areas was, according to Liddle, "quite unfit for human habitation; and as

\footnotetext{
${ }^{50}$ Ibid., 27 July 1849.

51 Ibid., 1 August 1849.

52 Ibid., 31 August 1849.

53 Ibid., September 1849.

${ }^{54}$ PP, 1850 [1275] xxi, 367, 'Report of the General Board of Health on the Epidemic Cholera of 1848 and 1849. Appendix B. Sanitary Report on Epidemic cholera as it prevailed in London by R. D. Grainger' ('Cholera in London'), 43-4.

55 Ibid., 44.

56 IPL, 'Trustees', 7 September 1849.

${ }^{57}$ GLRO, P83/MRY1/720, 'Trustees of Islington. Minutes of Special Committee appointed 7th September, 1849' ('Special'), 17 September 1849. Rutland Place is in Holloway, in the centre of Islington (I 9 in figure 1).
} 


\section{Gerry Kearns}

many of them are incapable of improvement, the only thing remaining to be done is to pull them down" ${ }^{58}$ It was not within the power of the Trustees to do this, and the house-to-house visitor admitted that Brand Street "has been much improved by the parochial officers during the last year; but the houses are much overcrowded and dirty, and almost unfit for habitation". ${ }^{59}$ It is not clear that the local authority had been neglectful in these cases, for it supplied bedsteads, mattresses, and food as well as medical attention. It responded promptly to Liddle's strictures, and by the end of September, the medical visitors engaged in house-to-house visitation reported that: "In numerous instances, families in the greatest want and inanition have, by the liberality of the trustees of this parish been relieved by proper and substantial food, whereby the bodily strength has been fortified and the access of disease prevented". 60 Grainger may have considered Brand Street to be "on the verge of the country" with respect to the rest of London but it was a particularly overcrowded district that had lost all rural vestiges. The registration material contains the following description:

Slaney Place, Brand Street, Holloway ... Many of these courts were at one time comparatively in the country, and their bad construction was neutralised by an allowance of fresh air; but they are now so hemmed in with new streets, that all their faults are aggravated to a degree that cannot be described without personal inspection. Common decency is hardly maintainable under these circumstances, and a "state of being" is produced detrimental to themselves and all surrounding them. ${ }^{61}$

Liddle ceased his inspection of the parish on 4 October $1849,{ }^{62}$ and a week later Gavin told the Trustees that they might suspend the house-to-house visitation. His concluding remarks seem a fair assessment of the co-operation of the Trustees during September 1849. Gavin wrote that: "I have only to add that the liberality of your Parish cannot but be viewed in a very satisfactory manner by all who value human life and to express a sincere desire that a renewal of the system to mitigate and prevent the ravages of cholera may long be deferred". 63

Cholera returned in 1853-4, and once again the Trustees' relations with the General Board of Health were at least cordial. An officer of the Board informed the Trustees that the: "Report to him of the arrangements made by the Trustees with reference to the prevailing epidemic was the most satisfactory he had received and that he had laid the report before Sir Benjamin Hall, The President of the Board of Health, and he had desired him to express his thanks to the Trustees for the steps they had taken." 64

The Board of Trustees also paid attention to the work of the Metropolitan Sanitary Commission. The Poor Law Board sent them three copies of the Commission's First

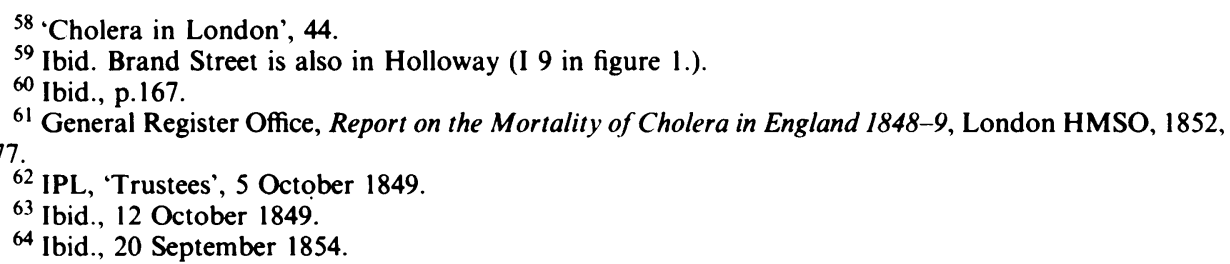




\section{Environmental management in Islington 1830-55}

Report. ${ }^{65}$ The Board of Trustees referred to its Highways Committee "extracts from the First Report... pointing out the advantages to be derived from a thorough cleansing of roads and public places". 66 These deliberations led the Trustees to have their roads cleaned by contract instead of by their own labourers. ${ }^{67}$ It decided to: "Draw up a handbill and to cause it to be printed and circulated in the poorer districts of the parish urging upon the inhabitants the necessity of increased cleanliness in their habitants and assisting in carrying out the sanitary measures of the Board in conformity with the recommendations contained in the Report of the Metropolitan Sanitary Commissioners." ${ }^{\text {"68 }}$ The Trustees were, in fact, involved in the Commission's investigations. In reponse to a request from the Commission, they asked their Highways Surveyor to: "Prepare a statement upon the sanitary condition of the parish and that the efforts made by the Board towards improving the poor districts by paving the various courts and alleys and endeavouring to furnish them with a proper supply of water be incorporated in such a statement." 69 The Highways Committee was also asked to answer ninety-seven questions forwarded by the Metropolitan Sanitary Commission. ${ }^{70}$

Pressures for sanitary measures were directed at the Board from private individuals, parochial officers, and government bodies. Most complaints were made by individuals, but with the Nuisances Removal and Disease Prevention Acts, the Medical Officers came more to the fore. During the cholera epidemics, the relative importance of these three groups changed: the Medical Officers became more vocal, and government bodies sent inspectors and regulations. The local authority maintained good relations with central government in the field of public health and was very responsive to suggestions from it. In many ways the complaints of individuals were generally the cheapest to deal with, and more extensive programmes were more seriously entertained under the pressure of a perceived crisis, although it is clear that the years between cholera epidemics saw effective initiatives alongside the run-of-the-mill policing of individual nuisances.

\section{SANITARY MEASURES AND THEIR RESULTS}

The people of Islington faced cholera armed largely with their regular legal machinery. The measures adopted during epidemics need to be seen in the context of public health efforts made during intervening periods. The major differences between epidemic years and others were matters of degree rather than kind: more nuisances cleared, more medical relief provided, more roads cleaned, and more roads repaired. This is very clear with regard to the removal of nuisances. Figure $5^{71}$ shows the total

\footnotetext{
${ }^{65}$ Ibid., 17 December 1847; PP, 1847-8 [911] [921] xxxii, 253, 293, 'Second Report of the Commissioners appointed to inquire whether any and what special measures may be requisite for the Improvement of the Metropolis'.

${ }_{66}$ IPL, 'Highways', 16 December 1847.

${ }^{67}$ Ibid., 21 December 1847.

68 Ibid., 6 January 1848, 11 January 1848.

${ }^{69}$ IPL, 'Trustees', 29 October 1847.

70 Ibid., 2 February 1848.

${ }^{71}$ IPL, 'Highways, 1831-47, I.P.L., 'Lamp', 1831-47.
} 


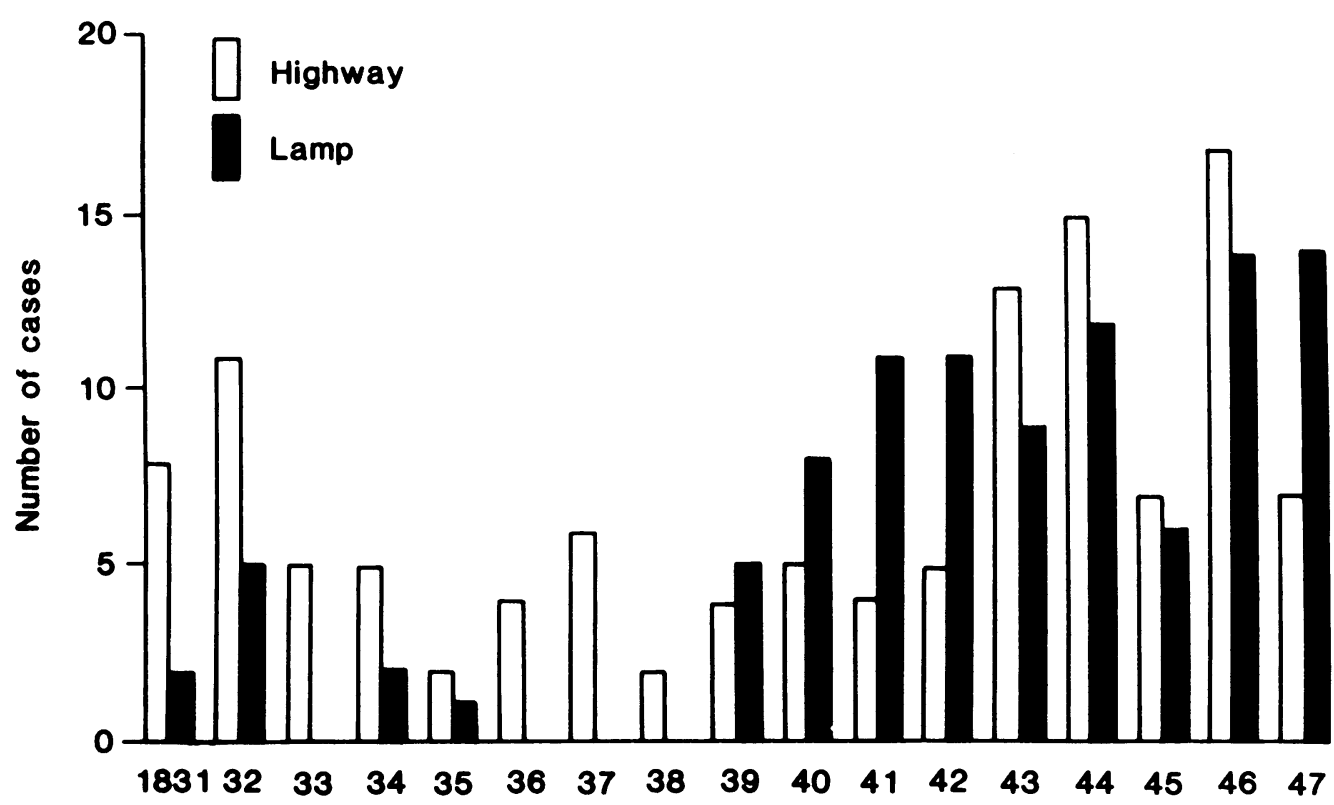

Figure 5 Nuisances reported to the Lamp and Highway Committees, 1831-47.

number of insanitary nuisances reported to the Lamp and Highway Committees from 1831 to 1847 . In all, 224 cases were referred to the committees during this period, with a maximum of 31 in 1846. From August 1847, the Trustees used the 1846 Nuisances Removal and Diseases Prevention Act in addition to the Local Act of 1825. Within the next year they dealt with eleven complaints under this new legislation. ${ }^{72}$ In August 1848, they switched to the 1848 Nuisances Removal and Diseases Prevention Act, and the Trustees took up twenty-six cases in this way before December $1848^{73}$ when responsibility for administering the Act was devolved to their new General Sanitary Committee. Within three months, the five new District Sanitary Committees received 714 reports of nuisances and succeeded in abating 577 of them; see table $1 .^{74}$ This remarkable explosion of activity attests to the efficiency of District Sanitary Committees acting under the apprehension of an imminent cholera epidemic.

These new committees were especially assiduous in cleaning houses. This was an activity rarely undertaken by the Highway and Lamp Committees in the preceding period. Filthy houses made up about one-tenth of the nuisances referred to in table 1 . After 10 March 1849, when the five District Committees were reduced to two, there are no summary tables in the Minutes and the reconstruction of particular "cases" tracing them through from week to week is extremely laborious. A systematic sample

\footnotetext{
72 IPL, 'Trustees', 4 August 1847, to 25 August 1848.

${ }^{73}$ Ibid., 25 August to 6 December 1848.

74 Ibid., 28 March 1849.
} 
TABLE 1: THE WORK OF THE DISTRICT SANITARY COMMITTEES; 6 DECEMBER 1848 TO 10 MARCH 1849

\begin{tabular}{lcccc}
\hline $\begin{array}{l}\text { Description } \\
\text { of Nuisance }\end{array}$ & $\begin{array}{l}\text { Cases } \\
\text { reported }\end{array}$ & $\begin{array}{l}\text { Nuisances } \\
\text { Removed }\end{array}$ & $\begin{array}{l}\text { Notices } \\
\text { Served }\end{array}$ & $\begin{array}{l}\text { Summons } \\
\text { Heard }\end{array}$ \\
\hline $\begin{array}{l}\text { Filthy } \\
\text { houses }\end{array}$ & 91 & 67 & 91 & 3 \\
$\begin{array}{l}\text { Filthy } \\
\text { drains }\end{array}$ & 156 & 114 & 162 & 4 \\
$\begin{array}{l}\text { Accumulations } \\
\text { of filth }\end{array}$ & 236 & 212 & 211 & 1 \\
$\begin{array}{l}\text { Filthy } \\
\text { privies }\end{array}$ & 153 & 146 & 137 & 1 \\
$\begin{array}{l}\text { Swine } \\
\text { Private } \\
\text { roads }\end{array}$ & 23 & 22 & 31 & \\
\hline Total & 55 & 16 & 519 & 9 \\
\hline
\end{tabular}

has been taken by tracing the first 411 cases encountered in the minutes of 1849 and the first 77 started in the minutes of 1850 . These samples are not exhaustive but they are large enough to establish the administrative efficiency and major concerns of the Committees in those two years. Of the 411 cases analysed for 1849 , about one-quarter relate to filthy houses; see table $2 .{ }^{75}$ This increased concern for filthy houses was primarily a response to the threat of cholera, for only one such case was found among the 77 cases examined for 1850 . From table 2, it may be seen that nearly half the nuisances reported were cleaned up without the General Sanitary Committee resorting to the legal sanctions available. In a further two-fifths of these cases, a preliminary notice to the owner from the Board of Trustees pointing out what powers

TABLE 2: PROCEEDINGS TAKEN FOR THE ABATEMENT OF NUISANCES; 10 MARCH TO END DECEMBER 1849

\begin{tabular}{lccccc}
\hline $\begin{array}{l}\text { Description } \\
\text { of Nuisance }\end{array}$ & $\begin{array}{l}\text { Cases } \\
\text { Reported }\end{array}$ & $\begin{array}{l}\text { Preliminary } \\
\text { Notices }\end{array}$ & $\begin{array}{l}\text { Notices } \\
\text { Served }\end{array}$ & $\begin{array}{l}\text { Threat of } \\
\text { Summons }\end{array}$ & $\begin{array}{l}\text { Summons } \\
\text { Heard }\end{array}$ \\
\hline $\begin{array}{l}\text { Filthy } \\
\text { houses }\end{array}$ & 110 & 47 & & 1 & \\
$\begin{array}{l}\text { Filthy } \\
\text { drains }\end{array}$ & 97 & 47 & 5 & 1 & 10 \\
$\begin{array}{l}\text { Accumulations } \\
\text { of filth }\end{array}$ & 103 & 24 & 18 & 10 & \\
$\begin{array}{l}\text { Filthy } \\
\text { privies }\end{array}$ & 94 & 41 & & & 10 \\
$\begin{array}{l}\text { Swine } \\
\text { Total }\end{array}$ & 711 & 162 & 23 & 12 & \\
\hline
\end{tabular}

${ }^{75}$ GLRO, P83/MRY1/721-31. 'St. Mary Islington District Sanitary Committees. Minutes 1848-56'. 


\section{Gerry Kearns}

were available to enforce removal was sufficient. In only one case in forty was the matter referred to a magistrate. Table 1 is somewhat less straightforward, since it treats separately each of the notices served to the occupiers of each house along a private road or drain that the Board had ordered the inhabitants to clean. In other words, cases reported and notices served were counted on a different basis by the committees in drawing up this table. It is, however, clear that the legal summons was rarely used, being required for about one in eighty of the nuisances removed. Figure 6 shows the time taken to clean up insanitary nuisances, over half of which were cleaned up within two weeks. Filthy drains took the longest to clean, whereas accumulations of filth could be removed relatively speedily. In 1848, things had proceeded more slowly, with most nuisances taking over five weeks to be cleaned up, whereas in 1850 the Committees were even more efficient than in 1849. The dramatic improvement between 1848 and 1849 may probably be attributed to increasing familiarity with the workings of the Act, rather than to the rise in cholera mortality.

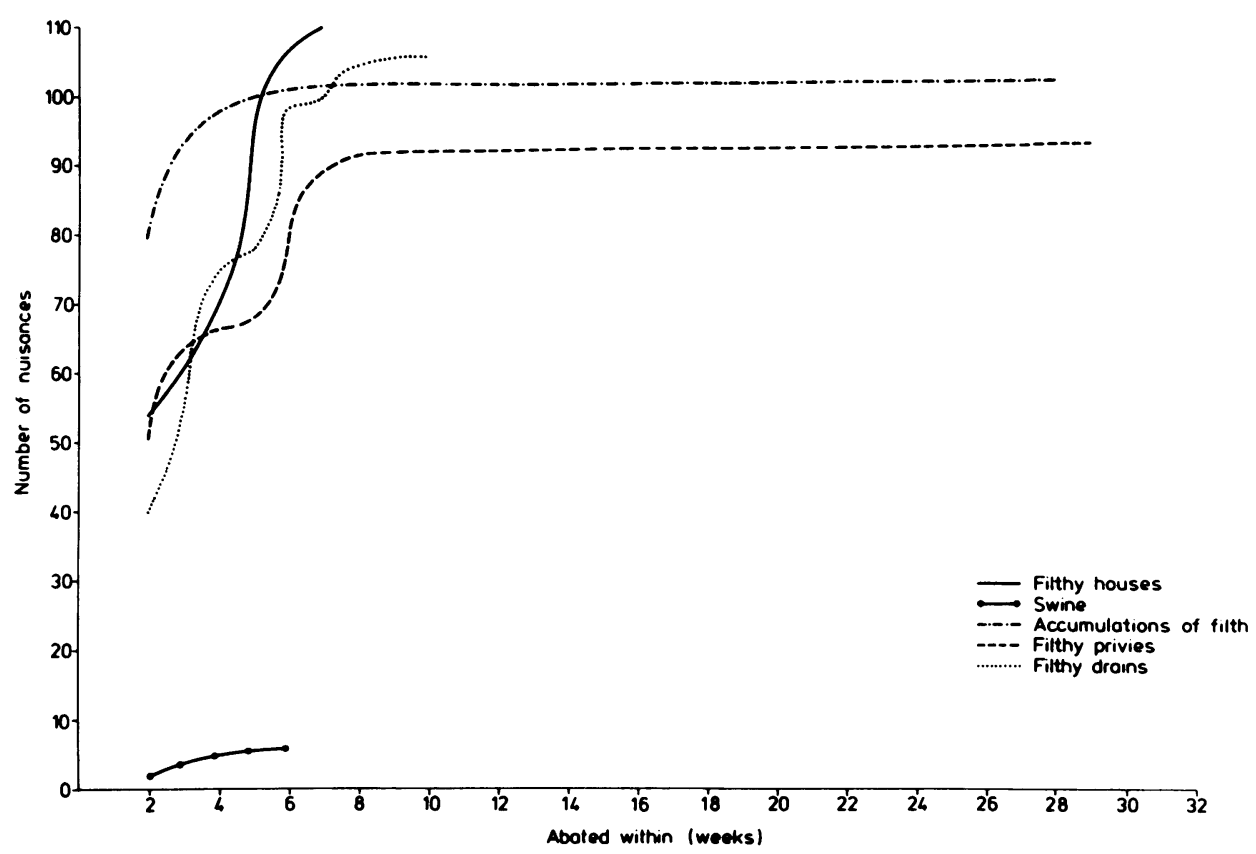

Figure 6 The time taken for the abatement of nuisances, 10th March to 31st December 1849.

As far as the abatement of nuisances is concerned, the first cholera epidemic (1832) saw a slight increase in activity, but there is a more significant and sustained rise between 1840 and 1847 and a dramatic rise from December 1848. These efforts did not fall back to the levels of 1847 after the second epidemic (1849) although the cleaning of filthy houses practically ceased. There were two critical differences between the first and second epidemics. In 1849, the General Sanitary Committee was supported by legal sanctions apparently contained in the Regulations of the national 
General Board of Health, whereas in 1832 the local boards were not given any "additional powers with regards to the removal of nuisances" and the national Central Board of Health was "not aware of any legal powers possessed by local boards to effect the cleansing of houses". ${ }^{76}$ Secondly, and more significantly, in Islington in 1849 a permanent body was set up; whereas in 1832, both the local and national bodies were rapidly dismantled once the epidemic was over.

It is more difficult to measure the level of medical activity occasioned by the cholera epidemics. The Cholera Committee of 15 December 1831 to 19 April 1832 disbursed nearly $£ 600$ that had been raised as "charitable contributions for the benefit of the poor"; of this, $£ 75$ went to pay for "medicines and medical apparatus including also printing and other contingences". 77 The Board of Health of 18 July to 30 October 1832 spent $£ 282.7 \mathrm{~s} .1 \frac{1}{2} \mathrm{~d}$. from the rates on "medicine, medical attendance, nurses, rent, beds, furniture, coals, candles and various other individual charges"; 78 this represented barely one-fortieth of the poor rates collected for the second half of 1832 . In addition, the Vestry voted a gratuity of $£ 50$ to the Medical Officer of the workhouse.

For 1848-9, more detailed costs may be derived from the Trustees' minutes. The Board of Trustees advertised that "any qualified medical practitioner of this parish as shall attend any poor persons attacked with illness who may apply to them for medical aid [will] be remunerated for their services to this Board". ${ }^{79}$ Seventeen medical people were reimbursed $£ 25.9 \mathrm{~s} .4 \mathrm{~d}$. under this head. ${ }^{80}$ The house-to-house visitation requested by the national General Board of Health cost $£ 34.13 \mathrm{~s} .0 \mathrm{~d}{ }^{81}$ The Trustees sent forty-six cholera patients to the Royal Free Hospital, thirty-eight of whom were sent directly by the Trustees' medical officers, ${ }^{82}$ at a cost to the Trustees of $£ 48.6 s .0 d .^{83}$ The medical assistants to the Medical Officers received $£ 45.3 s$. for their services in dispensing and preparing drugs. ${ }^{84}$ The employment of nurses in Brand Street ran up a bill of $£ 30 .{ }^{85} £ 15.15 s$. was paid to Holloway Dispensary "which supplied many drugs for the poor there and employed an extra person to dispense drugs". ${ }^{86}$ The workhouse Medical Officer was given $£ 20$ for treating tramps there and for making up the daily returns of cholera cases that were passed to Liddle at the

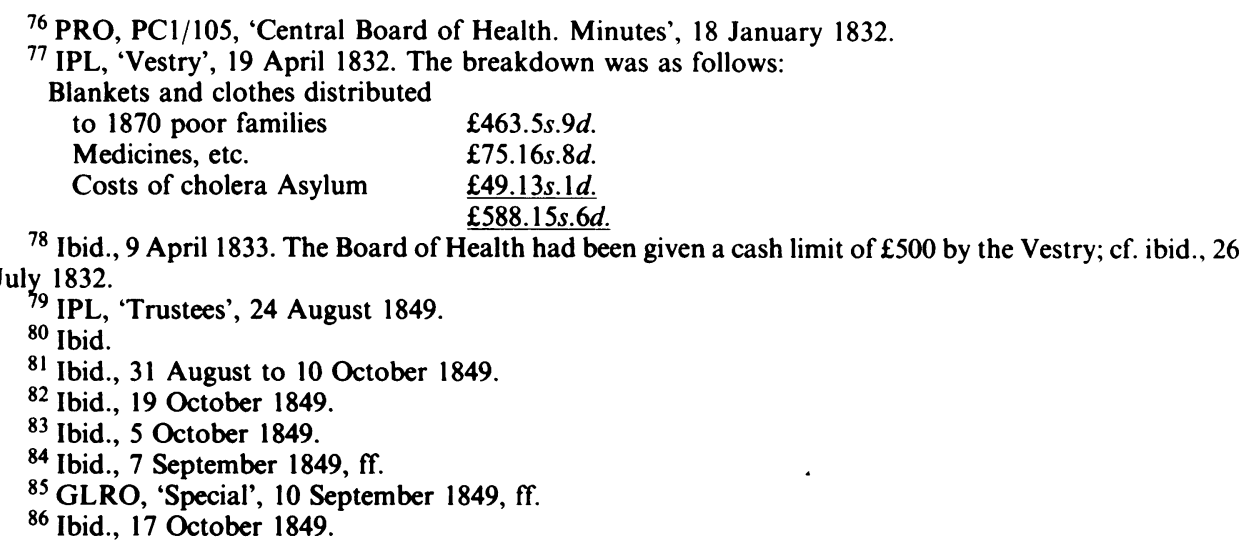


national General Board of Health. ${ }^{87}$ The keeper of the cholera House of Refuge was paid $£ 9.9 s .{ }^{88}$ and the Trustees' Medical Officers were given gratuities which totalled $\left\{232.10\right.$ s $^{89}$ From the minutes of the Special Committee, it appears that these gratuities were to comprehend the expenses incurred by the Medical Officers in dispensing drugs, estimated at $£ 25.5 s .{ }^{90}$ The salaries of the Medical Officers are not included in this list as they were normal expenses that were not altered in response to the cholera epidemic. This gives a total of $£ 663.15 \mathrm{~s} .4 \mathrm{~d} .^{91}$ which is a little over one-twentieth of the amount collected in Poor Rates for the second half of 1849.

It is clear that the specifically medical costs of dealing with the cholera epidemics were not great in comparison with the amount of rates raised. They need also to be compared to the background level of medical expenditure, to which they were an addition. From 1850 to 1855 , the accounts of the Vestry give details of normal medical expenditure, which averaged between $£ 400$ and $£ 600$ for each six months. There are no detailed breakdowns of expenditure for the period 1832 to 1848 . The major item of expenditure was the salary bill for the Medical Officers. Initially, the Board of Trustees employed one Medical Officer who was responsible for relief both within and without the workhouse. In September 1847, the workhouse Medical Officer, Robert Semple, wrote to the Trustees that:

Having been 34 years your Medical Officer, I hope you will pardon the following observations I venture to make. Two months ago an accident befell me ... [which] together with the growing infirmities arising from a long and laborious professional life spent in the service of the poor of the parish, render it advisable that I should not, for a time at least, take much bodily exercise. I have, therefore, respectfully to request that you will appoint my son joint Medical Officer with such remuneration as you may deem proper. ${ }^{92}$

The Board of Trustees told Sernple that it was his own responsibility to "make due provision for the discharge of the duties of his office during his indiposition". 93 Nevertheless, they did set up a committee to consider the system of medical relief in the parish. The committe concluded that "it is now physically impossible for one man duly to discharge the duties of Medical Officer of this Parish" and that Semple ought to be relieved of responsibility for the outdoor poor with the appointment of three additional Medical Officers. ${ }^{94}$ This complement was soon increased by two. The salary bill of the system of medical relief is the only available estimate of the normal medical expenses in the period 1832-48. From 1832 to 1847 , Semple’s $£ 200$ p.a. was the sole expense. From 1847 , Semple was paid $£ 120$ p.a., and the five district Medical

\footnotetext{
${ }^{87}$ IPL, 'Trustees', 7 November 1849.

88 Ibid.

89 Ibid.

${ }^{90}$ GLRO, 'Special', 23 October 1849.

91 The Vestry accounts for the second half of 1849 record "cholera expenses" of $£ 500$ against the Poor Rate; cf. IPL, 'Vestry', 13 December 1849. This is a suspiciously round figure although some of the expenses referred to in the minutes of the Board of Trustees may not have been disbursed by that date.

92 IPL, 'Trustees', 29 September 1847.

93 Ibid., 13 October 1847.

94 Ibid., 27 October 1847.
} 
Officers $£ 80$ each. Between 1832 and 1848, therefore, the annual medical bill of the Trustees rose from at least $£ 200$ to at least $£ 320$. In this context, the expense of the cholera measures of 1832 and 1849 are far from astronomical. In addition to the $£ 460$ paid for blankets and clothes, about $£ 400$ spent in 1832 may be termed cholera medical expenses, and about $£ 660$ in 1849 . What is striking is that the 1849 level would be an additional six months' expenditure based on the 1850-55 level of spending, whereas the 1832 expenditure would be three years' spending at the 1832-47 level. The purely medical costs, however, were small when set alongside the other costs of sanitary activity.

Street cleaning was one such expensive measure. By 1848, the Trustees were cleaning or repairing about 300 streets each year. The wealthier inhabitants lobbied the Highway Committee for attention, but poorer districts were more frequently dealt with following representations by the parish officers. The Trustees' employees frequently commented on the insanitary and dangerous state of the crowded courts and alleys of the parish. In July 1839, the Overseers of the Workhouse reported on "the bad state of the pavements and channels in the various courts near the Turnpike and in Duddies Rents and Ross Place, Lower Street, which occasioned the filth in those places to accumulate to produce infection". 95 In 1841, the Highways Surveyor was asked to clean "the courts and alleys in the parish as suggested by the Lamp Committee" and to put a Notice in Duddies Rents "cautioning all persons, not to throw filth on the Public Way and offering a reward of $58 /-$ for information that shall lead to the conviction of any person who shall act in contravention of such Notice". 96 Again, in 1843, the Surveyor was instructed to clean the courts and alleys of the parish $^{97}$ and the Highways Committee decided "that the clause of the Local Act requiring inhabitants to cleanse the footpaths in front of their houses be printed and circulated throughout the parish". 98 In 1846, the Committee determined that all courts and alleys should be cleaned once a week and they took on four additional labourers for the purpose. ${ }^{99}$ During the cholera epidemics, street cleaning was one of the precautionary measures taken. The Cholera Committee reported in December 1831 that it had requested the Overseers of the Workhouse:

To employ the paupers to cleanse the different lanes and courts throughout the parish which required it; and that accordingly the paupers under the personal superintendence of the overseers (whose diligence and attention to this duty have been most signal and praiseworthy) were employed in considerable numbers in washing and cleansing the same. ${ }^{100}$

The Islington Board of Health continued these "precautionary measures" and "a number of paupers provided with trucks and implements were immediately set to

\footnotetext{
${ }^{95}$ IPL, 'Highways', 1 August 1839. The area referred to was a very crowded one in the south-east of the parish.

96 Ibid., 17 June 1841.

97 Ibid., 14 December 1843.

98 Ibid., 28 December 1843.

99 Ibid., 3 September 1846.

100 IPL, 'Vestry', 15 December 1831.
} 


\section{Gerry Kearns}

work and much of the filth existing in different parts of the parish was effectually removed". 101

The cleaning of courts and alleys was not distinctively a crisis measure. The slightest suggestion that fever might be present in the parish regularly sent the Highway Committee scurrying to its pumps and brushes and brought the Dust Contractor before the Trustees to be reminded of the terms of his contract. What was significant, however, was the Vestry's willingness to allow the Trustees to extend their operations to private roads, over which they had no control and for which they had no responsibility. A remarkable Vestry decision of June 1848 empowered the Trustees to water all roads in the parish, except for the Turnpikes. ${ }^{102}$ Within six months, this cost $£ 2,000$, an increase of nearly one-third over the highways expenses of the previous six months. The Vestry did not repeat this liberality, but the General Sanitary Committee continued to direct that certain private roads should be cleaned or repaired. The trustees generally cleaned roads where their officers requested it, and the expansion of activity during cholera epidemics did not represent a change of policy. From 1841, the Board of Trustees' policy was given an institutional framework with the division of the parish into six areas for which reports were regularly solicited. The policies unique to the cholera epidemics were the direct employment of paupers by the Highways Committee in 1831-2 and the watering and maintenance of private roads in 1848-9. These special measures need to be set alongside the significant overall growth of the Board's activity between the two epidemics; see figure 3.

The problems occasioned by roads did not stop with their cleansing; the poor drainage of badly-made or un-made roads was a constant concern of the Board of Trustees. The records of the Highway Committee bear witness to the encouragment offered to builders to construct good roads that would be brought under the Board's control. Generally, the Board met one-third of the cost of making roads or paving courts for which the Board could then suitably assume responsibility under the Local Act. However, sanitary considerations were allowed to override these ground-rules. For example, in 1844 the Highways Committee recommended that:

In consequence of the accumulation of all kinds of rubbish which is injurious to the health of the neighbourhood, and the position of the road being altogether an exception to the general rule which governs the amount of contribution called for, the road be made upon Mr. Know paying one-third instead of two-thirds of the estimate. ${ }^{103}$

In 1846, the Trustees decreed that:

With a view of the sanitary conditions of the parish it be referred to the Committee for Highways to inquire which of the courts and alleys under the jurisdiction of the Board are not paved and to report such as they shall consider desirable to be paved. ${ }^{104}$

\footnotetext{
101 Ibid., 9 April 1833.

102 Ibid., 8 June 1848.

103 IPL, 'Highways', 11 January 1844. The road was in the south-west of the parish, an area already extensively developed (I 14 in figure 1).

104 IPL, 'Trustees', 14 October 1846.
} 


\title{
Environmental management in Islington 1830-55
}

When, during the epidemic of 1848-9, the Board of Trustees responded to the worries of the General Sanitary Committee by reducing the contributions it required from owners before making a road to one-third of the estimate, and in exhorting the Highways Surveyor to put in good repair the roads, courts, and alleys already under its jurisdiction, it was only following well-established precedents. The Board went beyond established practice in forcing new roads upon reluctant owners. It used its nuisances powers under the Local Act to summon owners to compound, or share, the expense of making a road. Willing parties were charged one-third of the estimate, whereas "those who refuse to pay... [were to be] proceeded against for their proportion of the full cost". ${ }^{105}$ This was a very aggressive policy. The work was completed first and the obdurate owners were prosecuted second. Characteristically, this avenue of legal redress proved very difficult.

Therefore, while the policy of imposing roads on reluctant owners in 1849 was novel, the argument that roads should be made up at the Trustees' expense in cases where it was a sanitary necessity was not: such a case had been made and acted upon in normal years. The Board of Trustees was proud of its work on the parish's roads, courts, and pavements. In writing of 'Exemptions from the Epidemic, and Results of Sanitary Improvements', Grainger told the national General Board of Health that "owing to the slow progress of sanitary improvements in the metropolis, but few instances of marked and decided benefits consequent upon their introduction can be adduced". ${ }^{106}$ Of the handful of examples of distinct improvements within London, Grainger cited the evidence of Dr Pearce, one of Islington's Medical Officers, about the transformation of some Irish courts after the Trustees had directed that they be cleaned and flagged. Pearce had written that:

\begin{abstract}
Some notion of the former state of the courts where the Irish lived may be gathered from the fact that, owing to the overflowing of privies, want of pavement, etc., the people were obliged to place bricks for the surgeon to step on to avoid the filth; the stench also was insufferable ... I think it is impossible that any more powerful proof of the efficiency of sanitary improvements can be deduced than those crowded, filthy Irish courts, which at one time were the hot beds of fever and erysipelas, have suffered very little during the late epidemic; and I think he must be determined to be sceptical, who can attribute this to any other cause than the vigorous sanitary precautions adopted and fully carried out by the Trustees of this parish. ${ }^{107}$
\end{abstract}

In Islington, therefore, sanitary measures were part of a general policy. In many respects the Board of Trustees' responses to the cholera epidemics represented differences of degree, rather than kind. Medical relief was certainly provided to a greater extent during the epidemics and many of the extra officers taken on were laid off as soon as the crisis had passed; and the General Sanitary Committee rejected two motions that would continue the free supply of drugs and medicines to the poor after the end of the 1849 epidemic. ${ }^{108}$ The making of roads was not greatly extended during

\footnotetext{
105 Ibid., 21 March 1849.

106 'Cholera in London', 78.

107 Ibid., 79.

${ }^{108}$ GLRO, 'Special', 23 October 1849.
} 


\section{Gerry Kearns}

the epidemics although a greater degree of compulsion was used in 1849. The two really distinctive responses to the threat of cholera were the tremendous number of filthy houses cleaned under the Regulations of the General Board of Health and the extensive watering of all roads during the second half of 1849 .

\section{THE OBSTACLES TO SANITARY MEASURES}

It is clear that any study of the local responses to cholera epidemics must not proceed on the assumption that only on these occasions did local authorities "discover" poverty or insanitary conditions. There is a clear implication in the Report of the General Board of Health on the epidemic of 1848-9, that the imposition of house-tohouse visitation on local authorities dragged them into their own dirty backyards for the first time:

The amount of sanitary evils of every kind detected whenever the system of house visitation was applied, and which till then had been unnoticed, is in fact one of the strongest proofs that could be adduced to show the necessity of efficient and constant medical inspection of the populous districts of London. ${ }^{109}$

Among the examples which Grainger cited in support of this observation were two relating to poor drainage in Islington. However, the Board of Trustees had continually inspected the parish, and was aware of the problem of drainage: it did not happen upon it for the first time in 1849. But the existence of sanitary evils in 1849 was advanced as evidence of neglect or inactivity by Grainger, who took their cause to be either ignorance or laziness. As I have suggested above, such claims cannot be assessed without a consideration of longer-term patterns of local activity, and particularly the obstacles encountered by sanitary measures. In three areas the Islington Board of Trustees met powerful impediments to its public health activities: the water company and commissions of sewers; the local constitution; and the defence of private property within the law. This is the case, not of a local authority gradually developing a set of criticisms of urban sanitary conditions in the mid-nineteenth century, but of one that was educated very quickly about the real distribution of power in society and about the effectiveness of the law.

The provision of water and sewerage services by private companies was a prominent concern of the public health movement. The dealings of the local authorities of Islington with these bodies confirm many of the worries expressed by public health propagandists about both the quality and quantity of services supplied. However, it is also clear that the local authority was unable to take matters into its own hands and contract on behalf of all parishioners for an improved supply. The Board of Trustees felt powerless to do more than await legislative intervention. Under the exceptional circumstances of 1832, the Islington Board of Health asked "the New River Company to afford a supply of water which was readily granted in abundance". 110 Each year the Board of Trustees purchased a supply of water for cleaning the streets. In 1846, the Highways Surveyor highlighted the insufficient

109 'Cholera in London', 126.

${ }^{110}$ IPL, 'Vestry', 9 April 1833. 


\section{Environmental management in Islington 1830-55}

supply of water in fifty of the poorer courts and alleys of the parish. ${ }^{111}$ The Trustees set up a "committee to inquire into the most effectual and economical means of obtaining a supply of water in the localities referred to in the Surveyor's Report". 112 This committee reported that, although only one court was completely without water, there was a need for a better provision in many others "to improve the sanitary conditions of the poorer districts of the parish". Following the findings of the Health of Towns Commission, the committee recommended that a constant supply be established, but noted that the cost would be very high and doubted whether the Board of Trustees was entitled to assume such a liability. It warned that "if it were to undertake to purchase water, the expenditure under that head would be liable to objection, and might possibly be successfully resisted before the Auditor, or by an appeal to the Quarter Sessions", and concluded, with regret, that: "The great desideratum is a constant supply introduced into all houses so as to be available for use at any time day or night, but this is the case in all parishes and is one which the powers of the Board will not reach and which nothing short of a general legislative enactment will remedy." 113 In 1847, the Medical Officer to the workhouse reached the same conclusion with respect to these dirty and unhealthy courts: "until the legislature enacts a sanitary Law, private exertions can do but little in averting the progress of Typhus Fever and other diseases presumed to be contagious". 114

The Board of Trustees' efforts to secure a comprehensive improvement in the drainage of the parish through the Commissions of Sewers reached a similar impasse. This is exemplified by the efforts the Board made to improve the drainage of Holloway, a district in centre of the parish. The subject was first raised by C. H. Hill in "a survey and report made and published gratuitously by me in July 1825 for the benefit of the Gentlemen of Holloway", 115 in which he suggested straightening the drainage lines and putting some larger drains in. Nothing was done. In 1832, Hill, then Surveyor to the Highways Committee, referred the matter to it, but again nothing was done. ${ }^{116}$ On 23 December 1833, "houses in Holloway Place, Loraine Terrace, Camden Place and the neighbourhood were from two to three feet deep [in drainage water] in their kitchens and gardens" and in January 1834, Hill produced another report for the Highways Committee. ${ }^{117}$ This report was referred to the Board of Trustees and the Highways Committee urged the Board to encourage the inhabitants of Holloway to pay for the necessary improvements "as they [the Highways Committee members] are of the opinion that the parties to be benefitted ought to provide the money before any of the works are commenced". 118 Hill estimated that the improvements might cost $£ 4,000$. The Trustees did nothing since the question appeared "to be taken up by the House of Commons" and government measures might render it unnecessary for the parish to spend any money in this area;

\footnotetext{
111 IPL, 'Trustees', 19 August 1846.

112 Ibid., 2 September 1846.

113 Ibid., 28 October 1846.

114 Ibid., 3 September 1847.

115 IPL, 'Highways', 23 January 1834.

116 Ibid., 5 July 1832.

117 Ibid., 23 January 1834.

118 Ibid., 20 February 1834.
} 


\section{Gerry Kearns}

it might be better if the parish acquired no further interests in sewerage and if the control of all sewers in the parish rested with the Commissions of Sewers; and, finally, since the Trustees did not have the necessary approval from the Vestry for such expenditure. ${ }^{119}$ The question of the drainage of Holloway was repeatedly raised by the Committee of the Board of Trustees, and in 1848 the Board wrote to the new Metropolitan Commission of Sewers which had been given reponsibility for the sewerage of the whole of London, on the subject. ${ }^{120}$ No reply to this is recorded. In 1849, one of the District Sanitary Committees made a special report to the Metropolitan Commission of Sewers. ${ }^{121}$ The Surveyor to the Commission replied that "there is at present no drainage for this place and it will be provided for in the general plans for drainage", ${ }^{22}$ but in 1850 the Trustees again complained of the Metropolitan Commission of Sewers' inactivity and asked for "immediate steps to provide a remedy for the evil". 123

In its dealings with the water companies and commissions of sewers, the local authority of Islington found that neither set of bodies was willing to make exceptions to the general rule of providing services only for payment. If these private enterprises were to continue to serve paying customers it was inconceivable that they should behave in a benevolent fashion, which might depress prices and implicitly commit them to a very broad view of their duties. The Trustees were unable to step in as effective consumers on behalf of the poor because the expense would be politically unacceptable. In the case of poorly-served middle-class areas, the differences in private-property owners' willingness to pay made it very difficult for the Trustees to co-ordinate large-scale works even in such wealthier districts.

In raising the question of the political acceptability of sanitary measures, one is broaching that of the responsibility of the Board of Trustees. The Trustees were answerable to the Vestry. The Vestry jealously watched all parish expenditure and would, through its assessors and auditors, disallow expenditure, such as repressing Sunday trading, with which it disagreed. This reluctance on the part of their masters lay behind the Trustees' nervousness in contemplating extensive environmental works.

The definition of "parish interest" was beset with problems. In 1841, the Surveyor felt unable to recommend that the drainage of one poor area of Islington be improved since "the Trustees of the Parish have not (I think) sufficient power to levy a rate upon the whole parish for the benefit of a particular district". ${ }^{24}$ Interpreted narrowly, this would have made all public health measures illegal since the funds were nearly always expended on improvements confined to particular areas. In general, however, the Vestry did not query the few hundred pounds spent annually on sanitary measures, but a particularly intransigent Vestry could paralyse the Trustees. This was a serious problem in the 1850s: between March 1851 and July 1851 all sanitary works

\footnotetext{
119 IPL. 'Trustees', 16 April 1834.

120 Ibid., 29 March 1848.

121 Ibid., 20 June 1849.

122 Ibid., 18 July 1849.

123 Ibid., 21 August 1850.

124 IPL, 'Highways', 4 March 1841.
} 


\section{Environmental management in Islington 1830-55}

were suspended, ${ }^{125}$ and in 1854 many of the Committees of the Board of Trustees ran up large overdrafts in the absence of Vestry funds. ${ }^{126}$

During the cholera epidemics, the Vestry were most eager that the Trustees should efficiently clean up the parish. The only mean act in their records was an (unsuccessful) amendment of 1833 which sought to negate the recommendation of a gratuity of $£ 50$ to the Surveyor for his efforts in patrolling the parish for public health dangers. ${ }^{127}$ Finer wrote of the tradesmen and shopkeepers of London vestrydom as "the narrowest and meanest class that England ever produced"128 and claimed they smashed the Public Health Act of 1848. However, in Islington with its Vestry packed with builders and tradesmen, particularly associated with the noxious trades, the Trustees did not fall victim to any concerted opposition to their use of public health legislation. Furthermore, while the parish was vehemently opposed to the centralization of the new Poor Law (1834), the Trustees were not censured for co-operating with central authorities in improving the environment. The constitution of the parish proved an obstacle to sanitary improvements insofar as the Vestry's veto of large-scale schemes of improvement confined the Trustees to the piecemeal removal of particular nuisances. They had no power to prevent nuisances from recurring or from being established. Thus they were unable to interfere when they received a letter "complaining that a person of the name of Martin has built a shed at Belle Isle which he intends for horse slaughtering purposes, and requesting the Board to prevent it". ${ }^{129}$ The Trustees tried to keep the parish clean by responding to complaints. But the large-scale engineering and water works they recognized as necessary were placed beyond them by the organization of local government finance. The ratepayers felt unable to raise the money among themselves and looked to the national purse. Thus the Vestry, keen for Parliament to take these matters under consideration, was not disposed to give the Trustees their head.

Even so constrained, there was plenty for the Trustees to concern themselves with. The most serious obstacle to their efforts at improving the environment in Islington came from the rights of private property owners. Under the Local Act, the Trustees could only act where nuisances threatened the parishioners' enjoyment of the public area of the parish. In general, the Board was reluctant to interfere if "the cause of the complaint appears to be on private property". ${ }^{130}$ On one occasion the Board would not prevent owners blocking channels, other than natural watercourses, which ran through their land for "the stoppage of the drains complained of is a question touching private right and... it is not desirable for the Board to interfere therewith". 131

The rights of property extended to many small businesses producing unpleasant smells. A Mr Cork who processed dung and had done so in south Islington for "upwards of forty years" replied to one complaint that his:

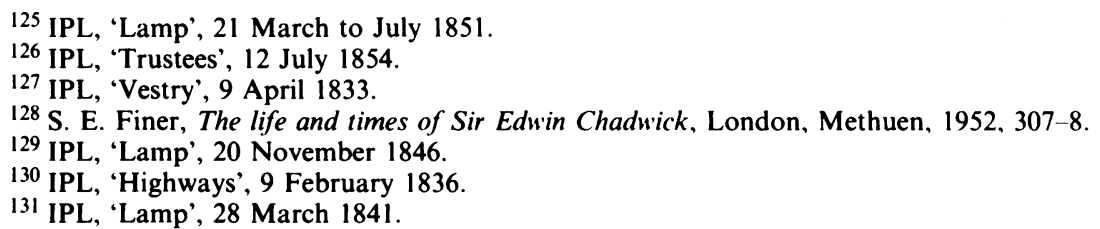




\title{
Gerry Kearns
}

Dung is worth to me from $15 /-$ to 20 /- per week and as the annoyance (if any) is only felt during the hot weather, I do hope my neighbours will not make an attempt under the circumstances, to deprive me of this source of income, it being a matter of consequence to me, although the amount is small, but, should such an attempt be made, I shall feel it my duty to resist it. ${ }^{132}$

The Lamp committee agreed that "the nuisance complained of if any is a private one". In Belle Isle in the north-west of the parish, there was a regular concentration of noxious trades including blood boiling, boiling seal oil, colour and varnish making, chemical works, fat melting, grease making, horse slaughtering, lucifer match making, manure processing, oxalic acid making, printing-ink making, and soap making. To this list of "offensive trades", the Inspector of Nuisances was disinclined to add pig breeding, which "is in comparison with the surrounding operations of a noxious nature here carried on, of little moment". ${ }^{133}$ Although the Inspector thought these smells produced "a marked susceptibility to disease" he was:

\begin{abstract}
Able to obtain but little evidence that could be relied on from persons directly or indirectly connected with the Trades referred to, some of them being peculiarly interested in the suppression of the truth, others either adverse or indifferent to the important nature of this inquiry, while some are even hardy enough to disclose their belief that heaps of bones to which the putrefying flesh still adheres, swarming with flies, and emiting carbonic acid gas, are constituents of a healthy occupation, or that the fumes of phosphoric acid are inoffensive. ${ }^{134}$
\end{abstract}

Strong stomachs owned sturdy gates, and the investigation of complaints often proved difficult. In one case, the Lamp Committee could not "form an opinion as to the extent of the nuisance arising from Mr. Pizey's premises, not being able to obtain admission thereto". ${ }^{135}$

It is difficult to resist the conclusion that legal officials went out of their way to make sanitary legislation unworkable. For example, in 1840, the Trustees complained to $\mathrm{Mr}$ Flight that "in consequence of the defective state of his dung carts the solid drops from them in transit through the parish". ${ }^{136}$ In fact, the carts belonged to a Mr Dodd and one of his drivers was taken into custody by the streetkeeper and brought before the Magistrate, but "it being the first offence the Magistrate discharged him with a reprimand". ${ }^{137}$ Another symptomatic case concerned a dust-shoot certified by two medical practitioners to be "an accumulation of offensive or noxious matter on the said premises . . l likely to be prejudicial to the health of the persons whose habitations are in the neighbourhood of the above mentioned premises". ${ }^{138}$ A month later, the Magistrate ordered its removal but the owner "threatened to resist the execution of the

\footnotetext{
132 Ibid., 21 August 1840. The dung-mixer was sited in Tyndale Place, which was in the relatively crowded south-eastern corner of Islington (K12 on figure 1).

${ }^{133}$ GLRO, P83/MRY1/723, 'St. Mary Islington. Eastern Sanitary Committee. Minute Book' ('Eastern Sanitary'), 16 April 1851.

134 Ibid.

135 IPL, 'Lamp' 20 July 1840. Pizey owned a bone-boiling works at Portland Place in south-east Islington (K12 on figure 1).

136 IPL, 'Trustees', 27 May 1840.

137 Ibid., 10 June 1840.

138 Ibid., 2 February 1848 . Once again the complaint refers to Belle Isle, Maiden Lane.
} 


\title{
Environmental management in Islington 1830-55
}

order". ${ }^{139}$ The Trustees sought the opinion of counsel, and Mr Bodkin QC advised that, under the Nuisances Removal and Diseases Prevention Act, "The matter removed must be the identical matter referred to by the order. It is now I apprehend impossible to show that the matter adjudicated upon on the 11 th February still remains, there may be similar matter emitting effusions equally offensive but this is not I think sufficient." 140 The delay caused by legal proceedings was frequently noted and the Inspector of Nuisances once bemoaned the "dangerous delay" occasioned by his having to bring medical certificates or notices from aggrieved parties before the Board of Trustees in advance of serving a notice or a summons in the offenders "where a prompt abatement is most urgently needed and essential for the prevention of disease". ${ }^{141}$ Yet the "nice" interpretation of Mr Bodkin meant that delays not only endangered health, they basically prejudiced any access to legal sanctions. Given the scope for obstruction by those against whom proceedings were being taken, this opinion effectively made it impossible to deal with any but fossilized nuisances.

The final nail in the coffin of effective legal sanctions was driven home in February 1849, when,

\begin{abstract}
On Wednesday the 7th, Mr. Wetherett as the representive of Mr. Baume, the owner of several houses in Experimental Gardens, which the Medical Officer had certified to be in a filthy and unwholesome condition [,] and upon hearing the Magistrate decided that the owner was not the proper party to be proceeded against, but the occupiers who were really the offending parties, in making and keeping their houses in a filthy condition were the parties liable and he dismissed the summons accordingly! The above decision will in great measure paralyse any efforts for purifying the houses of the poor, for if the occupiers of such houses were to be selected as the amenable parties their poverty would prevent them complying with the orders that might be made upon them and the consequences would be, that the execution of such orders would devolve upon your committee thus casting a heavy burden upon the parish funds. The propriety of continuing to call upon parties to cleanse houses remains in abeyance. ${ }^{42}$
\end{abstract}

The same point was urged by Joseph Heron, Town Clerk of Manchester in an attack on the Nuisances Removal and Disease Prevention Acts: "I do not see why the owner should be made liable at all. In many cases the nuisances arise by the acts of the tenants. over whom he has no control". ${ }^{143}$ So much for the responsibilities of property. The law consistently took the narrowest possible view of them.

The legal process proved unco-operative, expensive, and slow. The Board of Trustees only recovered their costs after a succesful prosecution. In many cases, proceedings were dropped because the nuisances were cleared or because "the parties had pleaded guilty and promised to remedy the evils and ... in order to give them an opportunity of so doing the Justices had suspended making the compulsory orders". ${ }^{144}$ Even a successful prosecution might not result in costs being recovered.

139 Ibid., 1 March 1848.

140 Ibid., 29 March 1848.

141 GLRO, 'Eastern Sanitary', 27 May 1851.

142 IPL, 'Trustees', 11 Febuary 1849.

143 PP, 1854-5 (224) xiii, p.413, 'Report of select Committee on the Public Health Bill and Nuisances Removal Amendment Bill' ('Public Health Bill') qq.69, 70, p.5.

${ }^{144}$ IPL, 'Trustees', 18 August 1847. 


\section{Gerry Kearns}

Miss Harriet Parkin was proceeded against because of a nuisance which "arises from dogs, half-decomposed dogs' meat, and the emptying by a trough at the back drawing-room window, all the soil, which is usually conveyed to the common sewer, by the water closets". ${ }^{145}$ Parkin refused to admit anyone to inspect her premises. ${ }^{146}$ The property belonged to the Marquess of Northampton and his agent, Boodle, wrote to the Trustees that:

We have... communicated the Marquess' intention to eject Miss Parkin for non-compliance with the Notice to repair [issued by Boodle under the terms of the ground lease]. ... We apprehend that the lady's habits and the unpleasant results consequent upon them do not amount to a breach of any covenant in the Lease under which she holds. From the representation contained in your Letter it appears to us that the Lady's friends would be more likely to be induced to interfere in the matter by the Parish taking it up on public grounds, than for the Landlord to take proceedings for breach of the Repairing Covenant under the lease, the result of which you are well aware must be a matter of much doubt under the circumstances. ${ }^{147}$

Parkin refused to clean up the nuisance and the Board of Trustees took her to court. ${ }^{148}$ She did not attend the hearing but in her absence was found guilty and the Board had the nuisance removed. The cost of doing so proved less than the legal costs associated with prosecuting the case. Parkin paid the costs of repairing the property but the Trustees did not succeed in getting her to pay their legal costs ${ }^{149}$ and she eventually threatened to sue them for trespass in abating the nuisance. ${ }^{150}$

The Highways Committee similarly had great difficulty in recovering its legal costs. It noted that "litigation in many cases would naturally ensue to the serious loss of the parish" so that, and putting a brave face on it, the Committee adopted a "milder and more persuasive course". ${ }^{151}$ Opponents of the Nuisances Removal and Diseases Prevention Acts were candid about their motives in being "quite content that we should be left under the common law of England". The representatives of the "offensive trades" thought "a manufacturer who has embarked a large sum of money, ought to have the security which an expensive process to go through gives". ${ }^{152}$ Small wonder that Lord Ashley exclaimed to Edwin Chadwick, his colleague on the national General Board of Health, that in implementing the regulations of their Board "the magistrates are against us". 153

The real obstacles to public health measures in Islington were not ignorance or laziness. The Islington Trustees were caught between a Vestry that could haul them before the auditors to account for any "illegal" expenditure and a magistracy that repeatedly frustrated their efforts to recover their costs from the offending parties. This second pressure seems to have been somewhat relieved in the $1850 \mathrm{~s}$, when the

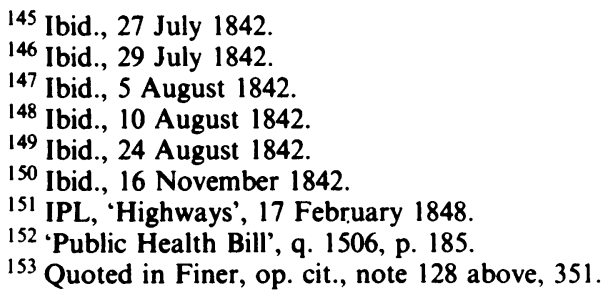


Trustees appear to have had greater success than earlier in securing costs from unsuccesful defendants. The activities of the Trustees were further circumscribed by the division of the parish into public and private domains, which placed most houses, some roads, and many drains beyond its control. It is true that the Vestry approved the limited crisis measures of the cholera epidemics of 1832 and 1854, and particularly 1849 , but the Trustees' real achievements were their expansion of activity between 1832 and 1849 and the sustained level of activity thereafter, and the making of so many courts and alleys in the late 1840s.

It is clear that Islington had a specific set of problems due to urban expansion and a spatially evolving division of labour in London that increasingly concentrated the smelly trades in Islington. The local authority responded to these developments, as well as to central encouragment and epidemic "crises". Nevertheless, the dynamic of change appears to have been largely internal. The Trustees received sufficient support from people unwilling to live with a deteriorating urban environment for the Board to develop a strategy of inspection, exhortation, bribery, and coercion in dealing with particular evils. The broader measures of water supply and drainage indeed awaited central interference, as Reddaway and Owen have emphasized. ${ }^{154}$ In this respect Edwin Chadwick was right to insist on the need for central direction, and Benjamin Hall, his successor at the General Board of Health, although initially disposed to rely upon local initiative, soon "discovered that a laissez-faire policy simply would not answer and that central government must act positively". ${ }^{155}$ Yet the people Chadwick and Hall had to convince entertained deeply-held suspicions of central government. It is all the more important, therefore, to insist that the crucial obstacles to effective local measures were not always the attitudes of the local authorities. The immediate context was given by rating systems, forms of taxation, the organization of the local franchise, and the defence of private property at law. ${ }^{156} \mathrm{~A}$ tendency to seek the significance of the extension of the moral reponsibility of government for environmental issues in nineteenth-century cities primarily in its assumed derivation from or consequences for political philosophy, may leave us with a view of the nineteenth century as at once both too reasonable and too reasoning. ${ }^{157}$ The "sanitary idea" threatened private property with a broad rather than narrow view of its responsibilities, yet in failing to make this a charge on the general community through national taxation it confronted ratepayers and landlords directly with the costs of urban improvement. Local opposition to public health measures was grounded in self-interest, not ignorance.

\footnotetext{
154 T. F. Reddaway, 'London in the nineteenth century: the fight for a water supply', Nineteenth Century' and After, 1950, 147: 118-30: Owen, op. cit., note 12 above, 47-101.

155 Ibid., 31.

156 G. Kearns, 'Private property and public health reform in England 1830-70', Social Sci. and Med., 1988, 26: 187-99.

157 J. Hart, 'Nineteenth-century social reform: a Tory interpretation of history', Past and Present, 1965. 31: $38-61$.
} 